\title{
Scientific epistemological beliefs and engagement of students
}

Crenças epistemológicas científicas e engajamento de estudantes

Creencias epistemológicas científicas y compromiso de los estudiantes

\author{
Hesteel Ven G. Ondap \\ hesteelven.ondap001@ deped.gov.ph \\ Crossing Bayabas National High School, Toril, Davao City, Philippines \\ https://orcid.org/0000-0002-5725-8251
}

\author{
Jhester S. Hornejas \\ jhesterhornejas@gmail.com \\ Sta. Cruz National High School, Sta. Cruz Davao del Sur, Philippines \\ https://orcid.org/0000-0002-5792-0399
}

\begin{abstract}
The main objective of this study was to determine which domain of scientific epistemological belief best influences engagement of students. The respondents of the study were the 126 Science Technology Engineering and Mathematics (STEM) students from a certain school in Toril for school year 2018 -2019 who were determined using the universal sampling method. Thus, all STEM students were chosen as respondents of this study. A quantitative non-experimental employing the correlational technique was utilized in this study. An adapted questionnaire was modified to contextualize in the local setting and was used in gathering the data. Mean, Pearson-r and Regression were the statistical tools employed in analyzing and interpreting the data. Results revealed that scientific epistemological beliefs and engagement of students were rated high. Further analysis revealed that a significant relationship exists between the two variables and scientific epistemological beliefs significantly influence engagement of students. Among the indicators of scientific epistemological beliefs, verification and improvement dimensions significantly influenced student engagement in their singular capacities but, the best influence of engagement of students was the verification dimension.
\end{abstract}

Keywords: science education, scientific epistemological beliefs, engagement of students, Philippines

\section{RESUMO}

O principal objetivo deste estudo foi determinar qual domínio da crença epistemológica científica melhor influencia o engajamento dos alunos. Os inquiridos do estudo foram os 126 alunos de Ciência, Tecnologia e Engenharia e Matemática (STEM) de uma determinada escola em Toril para o ano letivo 2018-2019 que foram determinados usando o método de amostragem universal. Assim, todos os alunos STEM foram escolhidos como respondentes deste estudo. Um quantitativo não experimental empregando a técnica correlacional foi utilizado neste estudo. Um questionário adaptado foi modificado para contextualizar no cenário local e foi utilizado na coleta de dados. Média, Pearson-r e Regressão foram as ferramentas estatísticas empregadas na análise e interpretação dos dados. Os resultados revelaram que as crenças epistemológicas científicas e o engajamento dos alunos foram classificados como altos. Uma análise mais aprofundada revelou que existe uma relação significativa entre as duas variáveis e as crenças epistemológicas científicas influenciam significativamente o engajamento dos alunos. Entre os indicadores de crenças epistemológicas científicas, as dimensões verificação e aprimoramento influenciaram significativamente o engajamento dos alunos em suas capacidades singulares, mas, a melhor influência do engajamento dos alunos foi a dimensão verificação.

Palavras-chave: ensino de ciências, crenças epistemológicas científicas, engajamento de estudantes, Filipinas

\section{RESUMEN}

El objetivo principal de este estudio fue determinar qué dominio de la creencia epistemológica científica influye mejor en el compromiso de los estudiantes. Los encuestados del estudio fueron los 126 estudiantes de Ciencia, Tecnología, Ingeniería y Matemáticas (STEM) de una determinada escuela en Toril para el año escolar 2018-2019 que se determinaron utilizando el método de muestreo universal. Por lo tanto, todos los estudiantes de STEM fueron elegidos como encuestados de este estudio. En este estudio se utilizó un método no experimental cuantitativo empleando la técnica correlacional. Se modificó un cuestionario adaptado para contextualizarlo en el entorno local y se utilizó para recopilar los datos. Media, Pearson-r y Regresión fueron las herramientas estadísticas empleadas en el análisis e interpretación de los datos. Los resultados revelaron que las creencias epistemológicas científicas y el compromiso de 
los estudiantes obtuvieron una calificación alta. Un análisis posterior reveló que existe una relación significativa entre las dos variables y las creencias epistemológicas científicas influyen significativamente en el compromiso de los estudiantes. Entre los indicadores de creencias epistemológicas científicas, las dimensiones de verificación y mejora influyeron significativamente en el compromiso de los estudiantes en sus capacidades singulares, pero la mayor influencia en el compromiso de los estudiantes fue la dimensión de verificación.

Palabras clave / descriptores: enseñanza de las ciencias, creencias epistemológicas científicas, compromiso de estudiantes, Filipinas

\section{INTRODUCTION}

Poor engagement of students in various academic and non-academic activities decreases effort which will eventually affect their self-esteem negatively. Each student has the ability to learn and become responsible and productive individuals, given a conducive learning environment. The lack of motivation towards academic activities which results in poor engagement in tasks is considered as one of the most prevailing academic problems today (Anderson, Carmichael, Harper \& Huang, 2009). In the Philippines, a study initiated by UNICEF in 2004 revealed that lack of personal interest (emotional engagement) is discovered to be one of the primary reasons why some high school students are not in school (Francisco, Gonzales \& Vargas, 2015).

Engagement of students is important because it is considered as one of the factors that determine the success of the school. If schools want to promote holistic development among their learners to succeed in future careers, improving engagement of students must be considered as one of their priorities. When students are engaged, they are interested to learn the essential knowledge and skills taught in school (Olson \& Peterson, 2015).

One of the factors that affects engagement of students is epistemological beliefs (scientific). It was revealed that scientific epistemological beliefs influence cognitive engagement of students in the classroom (Xie \& Huang, 2013). For example, students with naïve scientific epistemological beliefs who engaged in shallow processing have the tendency to believe that scientific knowledge is certain and learned from books, authorities and experts (Ravindran, Greene \& DeBacker, 2005). In the local setting, the acting school head of a certain school in Toril has asserted that most of the STEM students are observed to be disengaged and very passive during their science classes, despite the science learning activities employed by the teacher from the Science Learning Manuals/modules.

The researcher has not come across of a study dealing with the influence of scientific epistemological beliefs on the engagement of students in the local setting. It is in this context that the researcher is interested to determine whether scientific epistemological beliefs influence engagement among STEM students as this can lead to the development of action plans to address problem on engagement of students in science.

\section{Research Objectives}

The purpose of this study was to determine which domain of scientific epistemological beliefs best influences engagement of Science, Technology, Engineering and Mathematics (STEM) students. Specifically, this study has the following objectives:

1. To determine the level of students' scientific epistemological beliefs in term of:

1.1 verification dimension;

1.2 improvement dimension

1.3 resource dimension; and

1.4 certainty dimension.

2. To ascertain the level of engagement in terms of:

2.1 cognitive engagement;

2.2 behavior engagement; 


\section{3 emotional engagement; and}

2.4 social engagement.

3. To find out the significant relationship between scientific epistemological beliefs and engagement of students.

4. To determine which domain of scientific epistemological beliefs best influences engagement of students.

\section{Hypothesis}

The following null hypotheses were tested at 0.05 level of significance:

1. There is no significant relationship between scientific epistemological beliefs and engagement of students.

2. There is no domain of scientific epistemological beliefs that best influences engagement of students.

\section{THEORETICAL FOUNDATION}

This study is anchored on the proposition of Debacker, Greene and Ravindran (2005) which contends that epistemological belief has theoretical consistent relationship with engagement of students. This proposition is used in the study because it pinpointed the correlation between scientific epistemological beliefs and engagement of students. Moreover, the unveiled correlation clarifies why students with sophisticated epistemological beliefs (scientific) employ deep engagement in learning materials that they believe are useful (Pamuk, 2014).

The study of Zaleta (2014) among Grade Six science students supports the said proposition, as it was found that students with sophisticated epistemological beliefs in science show more engagement in open inquiry curriculum compared to those with naïve epistemological beliefs. In addition, Kruglanski's epistemic theory as cited by DeBacker and Crowson (2009) support that, students' engagement in a certain learning activity depends upon his/her personal belief that the activity is useful or functional.

Moreover, to explain further how students' epistemological beliefs (scientific) influence their personal view about knowledge, their ability and the learning process, the Theory of Epistemological Resources is to be utilized. This theory is about mental representation or processes. Epistemological resources refer to students' archives of past learning experiences that may be used as baseline in viewing a specific learning situation. The foundation of these resources is not limited to past learning experiences in a formal learning session but can also include day-to-day social conversation (Osterholm, 2009).

Another theory called self-system motivation theory is used to explain engagement of students. It assumes that engagement of students is a product from the interaction of the student with the situation and is reactive to changes in circumstantial characteristics. The quality of experience that the students can get from various school learning activities is related to their ability to adapt to various changes and feeling of competence (Wang, Fredricks, Ye, Hofkens and Linn, 2016).

\section{METHODS}

This chapter describes the study's research design, population and sample, research instrument, data collection, statistical tools, and ethical consideration.

\subsection{Research Design}

This study employed quantitative, descriptive, non-experimental design using correlational technique. This was used to determine the level of scientific epistemological beliefs and engagement of students and its relationship among Science, Technology, Engineering and Mathematics (STEM) students.

Quantitative research was used to objectively gather and utilize numerical data from a large population (chosen respondents) to determine the influence of scientific epistemological beliefs towards engagement of students in various science learning tasks/activities. This method focused on new data which were collected and analyzed from a large population at which the researcher's emotions and feelings were 
being ignored. Mafuwane (2012) also added that quantitative research results are expected to be duplicated or repeated regardless of the process or researcher, which is designed to surface the relationship between variables. In contrast to qualitative research, the researcher in this method is external or passive.

Descriptive research provided present factual quantitative description regarding the relationship between the two identified variables among the STEM students, using closed-ended survey questionnaires from Ozbay and Koksal (2016) for scientific epistemological beliefs; and Wang, Fredricks, Ye, Hofkens and Linn (2016) for engagement of students. As supported by Tichapondwa (2013) descriptive research design uses close-ended and unstructured open-ended survey questionnaires to describe the current generic view of respondents regarding the phenomenon under studied.

The study used a non-experimental research because it did not involve manipulation of variable. Quantitative analysis between the relationships of two variables was employed, using survey questionnaires. As pointed out by Bonds-Raacke and Raacke (2014) a non-experimental research does not rely on manipulating variables.

Lastly, this research used correlational technique. It was used to show the relationship (positive or negative correlation) between scientific epistemological beliefs and engagement of students, through analysis of data that provided new insights and views about the relationship of the two variables. Carlson (2017) explained that correlational research is a non-experimental research which measures the statistical connectedness between two uncontrollable variables.

This design was used because the researcher regarded it as congruent to the variables understudied, based from the discussions of the aforementioned related-literatures. The technique was also appropriate because the study aimed to determine the significant relationship of scientific epistemological beliefs and engagement of students, which was a study of correlation.

\subsection{Respondents and Sampling}

The study employed the universal sampling technique or "Census Method", which is referred to the complete enumeration or inclusion of a universe as respondents. A universe may be a place, a group of people or specific locality through which we collected the data and was necessary in some cases like population census, agriculture census, animal census, etc. for gaining vast knowledge (Farooq, 2013).

The respondents of the study included Grade 11 and Grade 12 senior high school students of Science, Technology, Engineering and Mathematics strand who were enrolled in the First Semester of the academic year 2018 - 2019 because they were the ones who provided useful information in the study. Excluded were the Grade 11 and Grade 12 senior high school students of HUMMS and Tech.Voc. strands of the same institution because the context of information gathered on the relationship of scientific epistemological beliefs and engagement of students were best fitted to science major students.

The students can withdraw from the research study if they committed falsification, plagiarism and other moral offenses or the respondents had health conditions and special needs. A participant can withdraw from the research study at anytime if they felt troubled or discomforted.

\subsection{Research Instrument}

A survey questionnaire which consisted of two parts was the primary tool or instrument was utilized in this study. The survey instrument for scientific epistemological beliefs established reliability with a Cronbach alpha coefficient of .802 , suggesting that the items had relatively high internal consistency since reliability coefficient of .70 or higher is considered reliable. The instrument was adapted and modified from the study of Ozbay and Koksal (2016). It consisted of 20 items equally distributed among four indicators and designed to determine the level of scientific epistemological beliefs based on verification dimension, improvement dimension, resource dimension and certainty dimension. The second part was adapted and modified from the study of Wang, Fredricks, Ye, Hofkens and Linn (2016). This was used to determine engagement of students in terms on four indicators; cognitive engagement, behavioral engagement, emotional engagement and social engagement. There were 20 items equally distributed among the four indicators. The survey instrument for engagement of students also established reliability with an alpha coefficient of .887 , suggesting that the items had relatively high internal consistency.

In evaluating the data on the level scientific epistemological beliefs, the researcher used the Fivepoint Likert Scale.

\section{Range of Means Descriptive Level}

\section{Interpretation}

Sapienza: International Journal of Interdisciplinary Studies | Vol. 3 | n. 1 | Jan-Mar | 2022 | e-ISSN: 2675-9780 


$\begin{array}{ll}\text { 4.20-5.00 } & \text { Very High } \\ 3.40-4.19 & \text { High } \\ 2.60-3.39 & \text { Moderate } \\ 1.80-2.59 & \text { Low } \\ 1.00-1.79 & \text { Very Low }\end{array}$

This indicates that the provision relating to scientific epistemological beliefs embodied in the item is always manifested.

This indicates that the provision relating to scientific epistemological beliefs embodied in the item is oftentimes manifested.

This indicates that the provision relating to scientific epistemological beliefs embodied in the item is sometimes manifested.

This indicates that the provision relating to scientific epistemological beliefs embodied in the item is seldom manifested.

This indicates that the provision relating to scientific epistemological beliefs embodied in the item is never manifested.

The following Likert scale was used to interpret the data gathered and determine the level of engagement of students.

\begin{tabular}{lll} 
Range of Means & \multicolumn{1}{c}{$\begin{array}{c}\text { Descriptive } \\
\text { Level }\end{array}$} & \multicolumn{1}{c}{$\begin{array}{c}\text { Interpretation } \\
\text { The measure relating to engagement of students embodied in } \\
\text { the item is always observed. }\end{array}$} \\
$3.20-5.00$ & Very High & $\begin{array}{l}\text { The measure relating to engagement of students embodied in } \\
\text { the item is often times observed. }\end{array}$ \\
$2.60-3.39$ & Moderate & $\begin{array}{l}\text { The measure relating to engagement of students embodied in } \\
\text { the item is sometimes observed. }\end{array}$
\end{tabular}

1.80-2.59 Low

1.00-1.79 Very Low
The measure relating to engagement of students embodied in the item is seldom observed.

The first draft of the research instrument was submitted to the research adviser for comments, suggestions and recommendations to improve its presentation with the corrections included and integrated. The final copies were submitted to the panel of experts for refinement. The final revision was made by incorporating the corrections, comments and suggestions gave by the expert validators; pilot test was conducted using Cronvach Alpha before the gathering of data.

\subsection{Data Gathering Procedure}

The necessary data was gathered personally by the researcher through the following steps. First, the researcher made a formal written communication addressed to the validators for the perusal and review of the questionnaires as instruments used in the research study. The said tools were subjected for comments, recommendation and suggestions; pilot test was conducted after the validation and pilot testing. Second, another framed letter was sent to the Acting School Head, asking permission to conduct the study with the 
endorsement letter from the Dean of the Graduate School. Third, upon approval from the Acting School Head of the school, the researcher assured that specific rules and conditions stipulated in the letter were followed.

Fourth, during the survey proper, the research questionnaires were distributed and administered personally by the researcher with the assistance of the adviser or subject teacher handling the class during the conduct of the survey to ensure $100 \%$ retrieval of the questionnaires. The actual survey was administered to a total of 126 respondents which corresponded to the total student population of the school and were STEM Senior High students of Grade 11 and 12. Lastly, the data gathered were tallied, tabulated, analyzed and interpreted confidentially accordingly, with the guidance of the statistician based on the purpose of the study.

\subsection{Data Analysis}

The following were the statistical tools utilized in processing the gathered data:

Mean. This was used to determine the level of scientific epistemological beliefs and engagement of students.

Pearson r. This statistical tool was used to determine the significance of the relationship between scientific epistemological beliefs and engagement of students.

Regression Analysis. This was utilized to determine which domain of scientific epistemological beliefs that significantly influence engagement of STEM students.

\subsection{Ethical Consideration}

There were considerable ethical issues and concerns that have specific ramifications for this quantitative inquest. Such issues and concerns may arise primarily from the methodology involved in this study. The ethical contests that were pertinent to this research concern the issues of the right to conduct the study, confidentiality and anonymity.

The researcher observed and followed full ethical standards in the conduct of the study following the study protocol assessments and standardized criteria, particularly in managing the population and data such as, but not limited to:

Voluntary participations. The Grade 11 and 12 STEM students of the selected school were given the free-will to participate without any form of consequence or penalty or loss of benefits. Therefore, after the purpose and the benefits of the study was described and presented to the participating school. Then, the rights of the respondents to contribute to the body of knowledge were carefully considered and adhered upon.

Privacy and confidentiality. The researcher kept private and with utmost confidentiality the respondents' personal information that may be required in the study.

Informed consent process. The research questionnaires were free of technical terms that make it easier for the respondents to understand. It gives the respondents a clear view of the benefits they may get after the conduct of this study. The research questionnaire was administered with the consent of the school principal.

Recruitment. The distribution of the respondents showed how the respondents were disseminated. Furthermore, the data collection procedures indicated, as well as how the questionnaire was administered, and the manner of respondents involved in the study.

Risks. The study did not involve in high risks of situations respondents may experience in physical, psychological or socio-economic concerns. The study just involves in their field of motivation towards learning.

Benefits. Chemistry teachers and other teachers teaching science-related courses will uplift their performance as an effective educator and may love even more with the kind of profession they have chosen. Moreover, there would be a significant change in the teaching and learning process in chemistry lessons in all academes for both private and public institutions. This may help the school administrators in terms of intensifying their monitoring program and implementing science curriculum revision in the basic education institutions.

Plagiarism. The study had no trace or evidence of misrepresentation of someone else's work as his own. The study undergone plagiarism detector like Grammarly or Turnitin software.

Fabrication. The study had no trace or evidence of intentional misinterpretation of what has been done. No making up of data and results, or purposefully putting forward conclusions that are not accurate.

Falsification. The study had no trace of purposefully misrepresenting the work to fit a model or theoretical expectation and have no evidence of over claiming or exaggeration. 
Conflict of Interest (COI). The study had no trace of conflict of interest like for example the disclosure of COI which is a set of conditions in which professional judgment concerning primary interest such as participants' welfare or the validity of the research tends to be influenced by a secondary interest such as financial or academic gains or recognitions.

Deceit. The study had no trace of misleading the respondents to any potential harm.

Authorship. The researcher of the study is a graduate of Bachelor of Secondary Education Major in Biological Science. The researcher of the study made a series of revisions because of the recommendations made by his adviser. The study also followed the standards of the University of Mindanao Ethics Review Committee for the guidelines of ethical consideration. After their approval, the study underwent pilot testing and the data collected was interpreted for the consistency of the research questionnaire.

\section{RESULTS}

Established in this chapter are data and analysis of findings based on the responses of the respondents on Scientific Epistemological Beliefs and Engagement of Students. The discussions are sequenced according to the following sub-headings: Level of Scientific Epistemological Beliefs; level of engagement of students; correlation between scientific epistemological beliefs and engagement of students, regression analysis of the influence of scientific epistemological belief on engagement of students.

\section{Level of Scientific Epistemological Beliefs}

Presented in Table 1 is the level of scientific epistemological beliefs. The overall mean score obtained by the scientific epistemological beliefs was 3.93 or high and the standard deviation was 0.40 .

Mean is used as statistical tool to determine the level of scientific epistemological beliefs among respondents. Specifically, the mean ratings of the indicators of scientific epistemological beliefs are disclosed as follows: verification dimension obtained a mean rating of 4.09 or high; improvement dimension had a mean rating of 3.93 or high; certainty dimension obtained a mean rating of 3.90 or high; and resource dimension had a mean rating of 3.79 or high. As presented in the table, verification dimension obtained the highest mean rating among the indicators of scientific epistemological beliefs while, resource dimension got the lowest mean.

Table 1

Level of Scientific Epistemological Beliefs

\begin{tabular}{lccc}
\hline \multicolumn{1}{c}{ Indicator } & SD & Mean & Descriptive Level \\
\hline Verification Dimension & 0.58 & 4.09 & High \\
Improvement Dimension & 0.58 & 3.93 & High \\
Resource Dimension & 0.50 & 3.79 & High \\
Certainty Dimension & 0.54 & 3.90 & High \\
Overall & $\mathbf{0 . 4 0}$ & $\mathbf{3 . 9 3}$ & High \\
\hline
\end{tabular}

\section{Level of Engagement of Students}

Presented in Table 2 is the summary of the level of engagement of students. The overall mean score obtained of engagement of students is 4.12 or high.

Mean is used as statistical tool to determine the level of engagement of students. Specifically, the mean ratings of the indicators of engagement of students were as follows: cognitive engagement had a mean rating of 4.25 with an interpretation of very high; emotional engagement had a mean rating of 4.11 described as high; behavioral engagement obtained a mean rating of 4.07 leveled as high; and social engagement obtained a mean rating of 4.04 leveled as high. As presented in the table, cognitive engagement got the highest mean rating; while, social engagement obtained the lowest mean. The high descriptive level as interpreted meant, that the level of engagement is observed often times.

Table 2 
Level of Engagement of Students

\begin{tabular}{lccc}
\hline \multicolumn{1}{c}{ Item } & SD & Mean & $\begin{array}{c}\text { Descriptive } \\
\text { Level }\end{array}$ \\
\hline Cognitive Engagement & 0.53 & 4.25 & Very High \\
Behavior Engagement & 0.49 & 4.07 & High \\
Emotional Engagement & 0.54 & 4.11 & High \\
Social Engagement & 0.54 & 4.04 & High \\
Overall & & & High \\
\hline
\end{tabular}

\section{Significance on the Relationship between Scientific Epistemological Beliefs and Engagement of Students}

Presented in Table 3 is the correlation between scientific epistemological beliefs and engagement of students. Pearson Product Moment Correlation was used to determine the relationship between scientific epistemological beliefs and engagement of students. As presented in the table, the overall computed r-value was .548 with the p-value less than 0.05 which was lesser than 0.05 level of significance. Thus, the result was significant and the null hypothesis which states that there is no relationship between scientific epistemological beliefs and engagement of students was rejected. This meant that a relationship between scientific epistemological beliefs and engagements of students existed.

Table 3

Significance on the Relationship between Scientific Epistemological Beliefs and Engagement of Students

Scientific

Epistemological

Beliefs

Verification

Dimension

Improvement

Dimension

Resource Dimension

Certainty Dimension

Overall

\begin{tabular}{|c|c|c|c|c|}
\hline $\begin{array}{c}\text { Cognitive } \\
\text { Engagement }\end{array}$ & $\begin{array}{c}\text { Behavior } \\
\text { Engagement }\end{array}$ & $\begin{array}{c}\text { Emotional } \\
\text { Engagement }\end{array}$ & $\begin{array}{c}\text { Social } \\
\text { Engagement } \\
\end{array}$ & Overall \\
\hline $\begin{array}{l}.534 * * \\
(.000)\end{array}$ & $\begin{array}{l}.371 * * \\
(.000)\end{array}$ & $\begin{array}{l}.427 * * \\
(.000)\end{array}$ & $\begin{array}{l}.307 * * \\
(.000)\end{array}$ & $\begin{array}{l}.525 * * \\
(.000)\end{array}$ \\
\hline $\begin{array}{l}.524 * * \\
(.000)\end{array}$ & $\begin{array}{l}.297 * * \\
(.001)\end{array}$ & $\begin{array}{l}.331 * * \\
(.000)\end{array}$ & $\begin{array}{l}.426 * * \\
(.000)\end{array}$ & $\begin{array}{l}.506 * * \\
(.000)\end{array}$ \\
\hline $\begin{array}{l}.307 * * \\
(.000) \\
.387 * * \\
(.000) \\
.601 * * \\
(.000)\end{array}$ & $\begin{array}{l}.123 \\
(.171) \\
.219 * \\
(.014) \\
.349 * * \\
(.000)\end{array}$ & $\begin{array}{l}.112 \\
(.212) \\
.213^{*} \\
(.017) \\
.376^{* *} \\
(.000)\end{array}$ & $\begin{array}{l}.143 \\
(.111) \\
.233 * * \\
(.009) \\
.383 * * \\
(.000)\end{array}$ & $\begin{array}{l}.219 * \\
(.014) \\
.337 * * \\
(.000) \\
.548 * * \\
(.000)\end{array}$ \\
\hline
\end{tabular}

\section{Significance on the Influence of Scientific Epistemological Beliefs on the Engagement of Students}

Shown in Table 4 is the regression analysis on scientific epistemological beliefs and engagement of students.

Regression Analysis is used to know the significant influence of scientific epistemological beliefs on engagement of students. As presented in the table, it showed four indicators of scientific epistemological beliefs namely: verification dimension, improvement dimension, resource dimension and certainty dimension produced an $\mathrm{R}$ value of $.585, \mathrm{R}^{2}$ value equivalent to $.343, \mathrm{~F}$ value of 15.762 and 
Table 4

Significance on the Influence of Scientific Epistemological Beliefs on the Engagement of Students

\begin{tabular}{|c|c|c|c|c|c|}
\hline \multicolumn{6}{|c|}{ Engagement } \\
\hline Indicators & & $\boldsymbol{B}$ & $\beta$ & $t$ & Sig. \\
\hline $\begin{array}{l}\text { Verification } \\
\text { Dimension }\end{array}$ & & .242 & .342 & 3.573 & .001 \\
\hline $\begin{array}{l}\text { Improvement } \\
\text { Dimension }\end{array}$ & & .192 & .270 & 2.820 & .006 \\
\hline Resource Dimension & & .064 & .079 & .983 & .328 \\
\hline Certainty Dimension & & .021 & .027 & .304 & .761 \\
\hline $\mathrm{R}$ & .585 & & & & \\
\hline $\mathrm{R}^{2}$ & .343 & & & & \\
\hline $\mathrm{F}$ & 15.762 & & & & \\
\hline $\mathrm{P}$ & .000 & & & & \\
\hline
\end{tabular}

p-value of .000 which denoted those scientific epistemological beliefs had significant influence on engagement of students. Thus, the null hypothesis was rejected. Further, the computed $\mathrm{R}^{2}$ value of 0.343 meant that $34.3 \%$ of the variance of engagement of students was due to the variance in scientific epistemological beliefs. This meant that $65.7 \%$ was attributed to other variables not covered in the study. Exploring the individual $\mathrm{p}$-value, verification dimension had .001, improvement dimension had .006, resource dimension had .328 and certainty dimension has .761. Among the indicators verification dimension and improvement dimension were found to be predictors of engagement of students with p-values lesser than 0.05 . However, further analysis revealed that verification dimension was the best predictor because it obtained the lowest p-value among indicators.

\section{DISCUSSIONS}

Presented in this chapter are the discussions of level of scientific epistemological beliefs, level of engagement of students, conclusion and recommendations on scientific epistemological beliefs and engagement of students.

\section{Scientific Epistemological Beliefs}

The high level of scientific epistemological beliefs indicates that students are totally aware about the nature of the knowledge acquired and the nature of their own learning, thus, they are to justify, transfer and apply the knowledge that they have learned in the classroom. Findings further revealed that scientific epistemological beliefs in terms of verification dimension got the highest overall mean score, indicates that oftentimes respondents believe in the use of experiments and scientific studies in understanding how things happen in the real world. Scientific concepts and processes introduced in books were products of curiosity and were tested or verified through experiments. This is in consonance with the assumption of Conley et al. (2004) that asking students to perform experiments and share differing results of experiments might lead in making them understand that answers to questions do not only come from authorities like books and literatures. Hence, hands-on experiments will lead students to develop epistemological awareness.

Findings revealed that improvement dimension was oftentimes observed. This means that students have high beliefs that the presence of new technology and the easy access of on-line information give way to new scientific discoveries and findings that may change what scientists thought to be true in the past. Likewise, scientist and science experts may change what they accept as correct through the presence of new related studies. The outcome is in line with the perspective of Conley et al. (2004) that students' epistemological beliefs about scientific knowledge may change over the course of instruction as they develop a more sophisticated belief in both the source and the certainty of knowledge.

Findings on the aspect of certainty dimension of scientific epistemological belief revealed that this indicator is also often times observed. This indicates that students have high beliefs that even scientists have still a lot to learn. Scientists among themselves may contradict about what is correct and what is not in 
science, particularly, because in science all questions may have several answers. This coincides with Arslantas (2015) discussion about epistemological beliefs stages based on four dimensions specifically, learners with independent knowledge who believes that majority of scientific knowledge contains unreliable contents and experts are not springs of knowledge.

It was revealed in the findings that scientific epistemological belief in terms of resource dimension got the least overall mean score yet, oftentimes observed. This indicates that students have high beliefs that people have to be critical of what is written in science articles, books, journals and literatures, as well as, what scientists say. It is important for students to realize that not everything you read in science book is correct. The findings agreed to the assertion of Terzi and Uyangör (2017) that it is imperative that students must be able to evaluate the dependability of scientific learning resources and authorities to judge whether the knowledge or a portion of its content is acceptable or bound to be rejected.

\section{Engagement of Students}

Findings indicate cognitive engagement of the students was always observed and obtained the highest overall mean score among the indicators of engagement of students. It implies students' effort to accomplish learning tasks in science and they make sure that it is right. Also, they are capable of managing academic adversities, utilize varied learning strategies, and self-regulate or use of metacognition. The outcome on cognitive engagement supports the idea of Phan, Ngu, and Alrashidi (2016) that students with high cognitive engagement are actively participating in the learning process by frequently asking relevant questions, continuously doing difficult tasks, despite of personal limitations, capable of managing academic adversities, utilize varied learning strategies and self-regulate/ use of varied matecognition in an effort to sustain and expand his/her own learning.

It was also revealed in the findings that engagement of students in terms of emotional engagement is often times observed. This means that students want to understand the importance of what they learn in science class. Students enjoy learning new things about science and feel excited towards science class. The findings are in consonance with the statement of Wang, Fredricks, Ye, Hofkens and Linn (2016) that emotional engagement is students' expression of positive feelings and interest toward teachers, peers, and to the learning process as a whole. It also includes students' emotional response to academic tasks like interest, enjoyment and the personal value of learning.

Findings on behavioral engagement of students revealed that it is often times observed. The result shows the students' persistence to accomplish difficult tasks in science. They try to accomplish the task even if it is perceived as hard or difficult. Also, it manifests students' focus during the class and compliance of homework on time. The findings are in line with the perspective of Wang, Fredricks, Ye Hofkens and Linn (2016) that behavioral engagement is manifested through students' attention, concentration and participation in the class. Promptness in submitting homework and adherence to classroom rules are also included as indicators of students' behavioral engagement.

Findings on social engagement of the students are oftentimes observed. It indicates that students like to work with their classmates in science class. It also shows that they are trying to understand and build ideas from others. They try to help other students who are struggling in understanding the lesson in science. The outcome on social engagement is parallel with the statement of Hurst, Wallace and Nixon (2013) that it is important for students to develop a healthy social interaction during the learning process primarily because they learn more with others, as interaction provides variety of perspectives which will make learning more meaningful.

\section{Significance on the Relationship between Scientific Epistemological Beliefs and Engagement of Students}

The test of relationship between variables reveals a significant relationship between scientific epistemological beliefs and engagement of students which leads in rejecting the null hypothesis of the study. This implies that engagement of students is dependent on scientific epistemological beliefs. Further, it implies that scientific epistemological belief has to do with engagement of students. Verification dimension as indicator of scientific epistemological beliefs is related to engagement of students. This is aligned to the proposition of Ravindran, Greene and DeBacker (2005) that epistemological belief (scientific) has theoretical consistent relationship to engagement of students (cognitive) and in line with the perspective of Pavlin-Bernardić et al. (2017) on the importance of conducting experiments to promote engagement of students in science class. 
Improvement dimension as indicator of scientific epistemological beliefs is related to engagement of students. This implies that improvement dimension has to do with the engagement of students. Resource dimension as an indicator of scientific epistemological beliefs is also related to the engagement of students. This implies that resource dimension has to do with the engagement of students. Certainty dimension as indicator of scientific epistemological beliefs is also found related to engagement of students. This implies that certainty dimension has to do with the engagement of students.

The findings are in consonance with the statement of Ismail (2017) about the positive correlation between epistemological beliefs and engagement of students, specifically, on cognitive engagement. To sum it up, students with naïve scientific epistemological beliefs who engaged (cognitively) in shallow processing has the tendency to believe that scientific knowledge are certain and are learned from books, authorities and experts (resource dimension). Differences in the level of epistemological beliefs among students influence the nature of their engagement (DeBacker \& Crowson, 2006).

\section{Significance on the Influence of Scientific Epistemological Beliefs on the Engagement of Students}

One of the important purposes of this study is the regression analysis determining which domains of scientific epistemological beliefs best influences engagement of students. It revealed that among the indicators of scientific epistemological beliefs, verification dimension and improvement dimension are found to have significant influenced on engagement of students. However, it came out in the study that the one that best influenced on engagement of students is verification dimension.

Additionally, the results confirm the claim of DeBacker and Crowson (2009) that, students' engagement in a certain learning activity depends upon his/her personal belief that the activity is useful or functional. This implies that the students' personal beliefs on the relevance and the application of the learning task affect their engagement towards the task. Students are engaged in activities which they believe are essential (useful) and provides avenue for them to construct their own meaning.

\section{CONCLUSION}

Based on the findings of the study, scientific epistemological beliefs significantly influence engagement of the students. Among the indicators, only verification and improvement dimensions have significant influenced on engagement of students. Likewise between these domains of scientific epistemological beliefs, verification dimension best influenced engagement of students.

Furthermore, overall level of scientific epistemological beliefs is high. Its indicators reveal the results: high for verification dimension, high for improvement dimension, high for certainty dimension and high for resource dimension. On the other hand, the overall level of engagement of students is high. Its indicators reveal the following results: very high for cognitive engagement, high for emotional engagement, high for behavioral engagement, and high for social engagement. Moreover, there is a significant relationship between scientific epistemological beliefs and engagement of students; and scientific epistemological beliefs in terms of verification and improvement dimensions significantly influence engagement of students.

This present study has determined the importance of engagement of students in terms of cognitive engagement. This study emphasized that students with high cognitive engagement exert effort to accomplish learning tasks in science and they make sure that it is right. Also, they are capable of managing academic adversities, utilize varied learning strategies, and self-regulate or use of metacognition. This indicates that it is important for teachers to be more sensitive on the cognitive engagement of the students in science class. Teachers must provide learning opportunities in which students can think of different ways in solving science problems. An opportunity that they, themselves will be able to construct the meaning of the lesson and its connection with the previous science concepts.

These findings confirmed to the proposition of Ravindran, Greene and DeBacker (2005) that epistemological belief (scientific) has theoretical consistent relationship to engagement of students (cognitive). It is also in line with DeBacker and Crowson (2009) statement that, students' engagement in a certain learning activity depends upon his/her personal belief that the activity is useful or functional.

Moreover, the respondents of the study limits only on Grade 11 and Grade 12 senior high school students of Science, Technology, Engineering and Mathematics strand who were enrolled in the First Semester of the academic year 2018 - 2019 because they were the ones who provided useful information in the study. Further, the researcher excluded the Grade 11 and Grade 12 senior high school students of HUMMS and Tech.Voc. strands of the same institution because the context of information gathered on the 
relationship of scientific epistemological beliefs and engagement of students were best fitted to science major students.

\section{RECOMMENDATION}

The researcher recommends that scientific epistemological beliefs be raised from high to very high, most particularly on the resource dimension, which was only the lowest level. This may be done by including topics about the use of research-based teaching strategies in science that develop students' scientific epistemological beliefs during the School Learning Action Cell (SLAC) sessions, seminars and trainings of science teachers. This is important to improve and cater students' scientific epistemological in terms of resource dimension. It is suggested that the implementation, monitoring and evaluation of the program may be spearheaded by DepEd Education Program Specialists in science and school principals.

On the other hand, the high level of engagement of students can also be raised from high to very high. It could be raised to very high level by conducting reorientation among science teachers about the importance of engagement of students in class. Engagement of students should also be included as part of the topics to be discussed during the Teachers Induction Program (TIP) for the newly hired teachers. Hence, making them more equip in dealing with disengaged students.

Lastly, significant relationship between scientific epistemological beliefs and engagement of students suggests that the Department of Education and the Commission of Higher Education must continuously conduct in-service seminars that will give science teachers clear conception about the influence of scientific epistemological beliefs on the engagement of students. The researcher recommends that a further research regarding the other factors that are associated with engagement of students will be conducted. Further studies must be conducted to validate the result of the present study.

\section{REFERENCES}

Anderson, G., Carmichael, K. Y., Harper, T. J., \& Huang, T. (2009). Student engagement in higher education: Theoretical perspectives and practical approaches for diverse populations. New York and London: Routledge.

Arslantas, H. A. (2015). Epistemological beliefs and academic achievement. Journal of Education and Training Studies, 4(1), 2324-8068.

Bonds-Raacke, J. M., \& Raacke, J. D. (2014). Non experimental Research Methods from Research Methods: Are You Equipped. Retrieved from https://he.kendallhunt.com/sites/default/files/uploadedFiles/Kendall_Hunt/Content/Higher_Education/Uploads/ Bonds_Raacke_Research_2e_Ch4.pdf

Carlson, J. (2017). Correlational research: Definition, types and examples. Retrieved From https://www.lifepersona.com/correlational research-definition-types-and-examples

Conley, A. M., Pintrich, P. R., Vekiri, I., \& Harrison, D. (2004). Changes in epistemological beliefs in elementary science students. Contemporary Educational Psychology, 29, 186-204.

DeBacker, T. K., \& Crowson, H. M. (2006). Influences on cognitive engagement: Epistemological beliefs and need for closure. British Journal of Educational Psychology, 76(3), 535.

DeBacker, T. K., \& Crowson, H. M. (2009). The influence of need for closure on learning and teaching. Educational Psychology Review, 21, 303-323.

Farooq, U. (2013). What is census method of data collection, advantages and disadvantages. Retrieved from $\mathrm{http} /$ /www.studylecturenotes.com/social-research-methodology/what-is-census-method-of-datacollectionadvantages-disadvantages

Francisco, M. B., Gonzales, R. D. L. C., \& Vargas, M. A. S. (2015). Student engagement: Associations with teachers and peers as motivators. International Journal of Educational Investigations, 2(11), 1-17. Retrieved from http://www.ijeionline.com/attachments/article/48/IJEI.Vol.2.No.11.01.pdf

Hurst, B., Wallace, R., \& Nixon, S. B. (2013). The impact of social interaction on student learning. Reading Horizons, 52(4), 5. Retrieved from http://scholarworks.wmich.edu/cgi/viewcontent.cgi?article=3105\&context=reading_horizons

Ismail, A. A. M. (2017). EFL teachers' epistemological beliefs and their assessment orientations. International Journal of Applied Linguistics and English Literature, 6(1), 2200-3452.

Mafuwane, B. M. (2012). Chapter 4 research design and methodology. University of Pretoria, 67-95. Retrieved from https://repository.up.ac.za/bitstream/handle/22 63/24016/04chapter4.pdf?sequence=5 
Olson, A. L., \& Peterson, R. L. (2015). Student engagement, strategy brief. Retrieved from http://k12engagement.unl.edu/student-engagement

Österholm, M. (2009). Theories of epistemological beliefs and communication: unifying attempt. Department of Mathematics, Technology and Science Education Umeå Mathematics Education Research Centre, 4, $257-264$.

Ozbay, H. E., \& Koksal, M. S. (2015). Relationship between middle school students' frequency of participation in lab activities and scientific epistemological beliefs: Turkish case. International Journal Modern Education and Computer Science, 12, 1-8. Retrieved from http://www.mecs-press.org/ijmecs/ijmecs-v7-n12/IJMECS-V7N12-1.pdf

Pamuk, S. (2014). Multilevel analysis of students' science achievement in relation to constructivist learning environment perceptions, epistemological beliefs, self-regulation and science teachers' characteristics (Doctoral dissertation, Middle East Technical University). Retrieved from http://etd.lib.metu.edu.tr/upload/12617892/index.pdf

Phan, H. P., Ngu, B. H., \& Alrashidi, O. (2016). Role of student well-being: A study using structural equation modeling. Psychological Reports, 119(1), 77-105. Retrieved from https://doi.org/10.1177/0033294116656819

Pavlin-Bernardić, N., Putarek, V., Rovan, D., Petričević, E., \& Vlahović-Štetić, V. (2017). Students' engagement in learning physics: A subject-specific approach.

Ravindran, B., Greene, B. A., \& DeBacker, T. K. (2005). Predicting preservice teachers' cognitive engagement with goals and epistemological beliefs.The Journal of Educational Research, 98(4), 222-232. Retrieved from https://search.proquest. com/docview/204198731 ?accountid=31259

Terzi, A. R., \& Uyangör, N. (2017). An analysis of the relationship between scientific epistemological beliefs and educational philosophies: A research on formation teacher candidates. Universal Journal of Educational Research, 5(12), 2171-2177.

Tichapondwa, S. M. (2013). Preparing your dissertation at a distance: A research guide. Retrieved from http://www.sadc.int/files/3713/7821/2867/

Dissertation_PDF.pdf

Wang, M. T., Fredricks, J. A., Ye, F., Hofkens, T. L., \& Linn, J. S. (2016). The math and science engagement scales: Scale development, validation, and psychometric properties. Learning and Instruction, 43. Retrieved from 16e26.cadrek12.org/sites/default/files/Wangarticle1.pdf

Xie, K., \& Huang, K. (2013). The role of beliefs and motivation in asynchronous online learning in college-level classes. Journal of Educational Computing Research, 50(3), 315 - 341. Retrieved from https://doi.org/10.2190/EC.50.3.b

Zaleta, K. L. (2014). The effects of gender and type of inquiry curriculum on sixth grade students' science process skills and epistemological beliefs in science (Doctoral dissertation, Western Connecticut State University). Retrieved from

https://repository.wcsu.edu/cgi/viewcontent.cgi?referer=https://www.google.com.ph/\&httpsredir=1\&article=10 $39 \&$ context=educationdis 